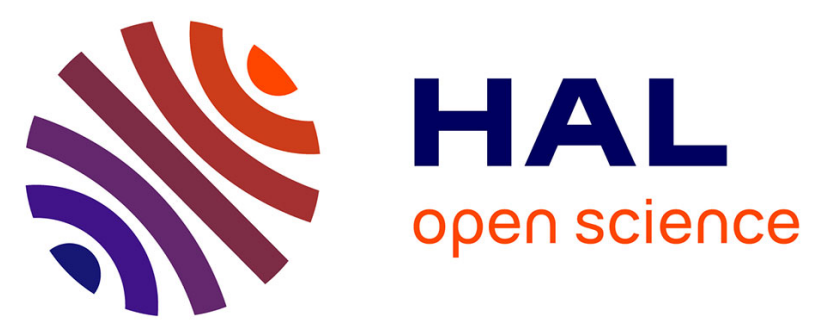

\title{
Spatial and temporal variability of land CO 2 fluxes estimated with remote sensing and analysis data over western Eurasia
}

Sébastien Lafont, Laurent Kergoat, Gérard Dedieu, Anne Chevillard, Ute Karstens, Olaf Kolle

\section{To cite this version:}

Sébastien Lafont, Laurent Kergoat, Gérard Dedieu, Anne Chevillard, Ute Karstens, et al.. Spatial and temporal variability of land CO 2 fluxes estimated with remote sensing and analysis data over western Eurasia. Tellus B - Chemical and Physical Meteorology, 2002, 54 (5), pp.820-833. 10.3402/tellusb.v54i5.16732 . hal-03127121

\section{HAL Id: hal-03127121 \\ https://hal.science/hal-03127121}

Submitted on 3 May 2021

HAL is a multi-disciplinary open access archive for the deposit and dissemination of scientific research documents, whether they are published or not. The documents may come from teaching and research institutions in France or abroad, or from public or private research centers.
L'archive ouverte pluridisciplinaire HAL, est destinée au dépôt et à la diffusion de documents scientifiques de niveau recherche, publiés ou non, émanant des établissements d'enseignement et de recherche français ou étrangers, des laboratoires publics ou privés. 


\title{
Spatial and temporal variability of land $\mathrm{CO}_{2}$ fluxes estimated with remote sensing and analysis data over western Eurasia
}

\author{
Sébastien Lafont, Laurent Kergoat, Gérard Dedieu, Anne Chevillard, Ute \\ Karstens \& Olaf Kolle
}

To cite this article: Sébastien Lafont, Laurent Kergoat, Gérard Dedieu, Anne Chevillard, Ute Karstens \& Olaf Kolle (2002) Spatial and temporal variability of land $\mathrm{CO}_{2}$ fluxes estimated with remote sensing and analysis data over western Eurasia, Tellus B: Chemical and Physical Meteorology, 54:5, 820-833, DOI: 10.3402/tellusb.v54i5.16732

To link to this article: https://doi.org/10.3402/tellusb.v54i5.16732

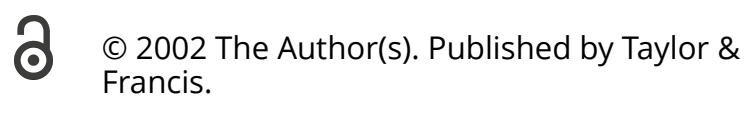

曲 Published online: 15 Dec 2016.

Submit your article to this journal $\pi$

\section{LIIIte views: 117}

Q View related articles $\triangle$

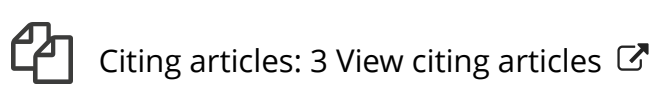




\title{
Spatial and temporal variability of land $\mathrm{CO}_{2}$ fluxes estimated with remote sensing and analysis data over western Eurasia
}

\author{
By SÉBASTIEN LAFONT ${ }^{\text {** }}$, LAURENT KERGOAT ${ }^{\mathrm{b}}$, GÉRARD DEDIEU $^{\mathrm{a}}$, ANNE CHEVILLARD ${ }^{\mathrm{c}}$, UTE \\ KARSTENS ${ }^{\mathrm{d}}$ and OLAF KOLLE ${ }^{\mathrm{e}}$, ${ }^{\mathrm{a}}$ CESBIO (CNRS/CNES/UPS), 18 av. E. Belin, 31401 Toulouse, France; \\ ${ }^{\mathrm{b}}$ LET (CNRS/UPS), 13 av. Col. Roche, Toulouse, France; ' ${ }^{\mathrm{C} S C E}$ (CEA), l'Orme des Merisiers, Gif-sur-Yvette, \\ France; ${ }^{\mathrm{d}}$ MPI-MET, Hamburg, Germany; ${ }^{\mathrm{e}} \mathrm{MPI}-G B C$, Jena, Germany
}

(Manuscript received 2 July 2001; in final form 28 February 2002)

\begin{abstract}
The Eurosiberian Carbonflux project was designed to address the feasibility of inferring the regional carbon balance over Europe and Siberia from a hierarchy of models and atmospheric $\mathrm{CO}_{2}$ measurements over the continent. Such atmospheric $\mathrm{CO}_{2}$ concentrations result from the combination of connective boundary layer dynamics, synoptic events, large-scale transport of $\mathrm{CO}_{2}$, and regional surface fluxes and depend on the variability of these processes in time and space. In this paper we investigate the spatial and temporal variability of the land surface $\mathrm{CO}_{2}$ fluxes derived from the TURC model. This productivity model is driven by satellite NDVI and forced by ECMWF or REMO meteorology. We first present an analysis of recent $\mathrm{CO}_{2}$ flux measurements over temperate and boreal forests, which are used to update the TURC model. A strong linear relationship has been found between maximum hourly $\mathrm{CO}_{2}$ fluxes and the mean annual air temperature, showing that boreal biomes have a lower photosynthetic capacity than temperate ones. Then, model input consistency and simulated $\mathrm{CO}_{2}$ flux accuracy are evaluated against local measurements from two sites in Russia. Finally, the spatial and temporal patterns of the daily $\mathrm{CO}_{2}$ fluxes over Eurasia are analysed. We show that, during the growing season (spring and summer), the daily $\mathrm{CO}_{2}$ fluxes display characteristic spatial patterns of positive and negative fluxes at the synoptic scale. These patterns are found to correspond to cloudy areas (areas with low incoming radiation) and to follow the motion of cloud cover areas over the whole domain. As a consequence, we argue that covariations of surface $\mathrm{CO}_{2}$ fluxes and atmospheric transport at the synoptic scale may impact $\mathrm{CO}_{2}$ concentrations over continents and need to be investigated.
\end{abstract}

\section{Introduction}

The terrestrial biosphere is an important and poorly known component of the global carbon cycle. Assessments of $\mathrm{CO}_{2}$ fluxes are mainly available at two scales: the local and the global scale. At the local scale, a number of $\mathrm{CO}_{2}$ flux measurements based on eddy covariance systems have been organized in net-

*Corresponding author. e-mail: sebastien.lafont@cesbio.cnes.fr works, like FLUXNET (Baldocchi et al., 2001a) and EUROFLUX (Valentini et al., 2000). These networks have resulted in significant advances in the characterisation of carbon uptake and release by ecosystems. Eddy covariance measurements, however, face challenging difficulties to produce $\mathrm{CO}_{2}$ exchanges integrated over time and space, due to gap-filling and accuracy problems and due to a typical footprint of the order of 25 ha. On the other hand, atmospheric inverse transport studies based on the monitoring of $\mathrm{CO}_{2}$ concentration in the atmosphere give access to surface $\mathrm{CO}_{2}$ fluxes integrated 
over large areas, typically from latitudinal bands to continents (Ciais et al., 1995; Fan et al., 1998; Bousquet et al., 1999). These studies are mainly based on $\mathrm{CO}_{2}$ data obtained from marine sites, primarily because $\left[\mathrm{CO}_{2}\right]$ over continents shows a strong variability, resulting from large and highly variable surface fluxes and complex mixing of the atmosphere. As a result, the partitioning of the retrieved surface $\mathrm{CO}_{2}$ fluxes between different continents and regions is still poorly constrained (Fan et al., 1998; Bousquet et al., 2000). In this context, the Eurosiberian Carbonflux project was designed to address the feasibility of inferring the regional carbon balance over Europe and Siberia from a hierarchy of models and atmospheric $\mathrm{CO}_{2}$ measurements over the continent. One of the key questions is to understand the influence of local versus remote $\mathrm{CO}_{2}$ sources or sinks on the $\mathrm{CO}_{2}$ concentrations sampled at different levels in the atmosphere. These concentrations result from the combination of convective boundary layer (CBL) dynamics, synoptic events, large-scale transport of $\mathrm{CO}_{2}$, regional surface fluxes and their variability in time and space.

In this paper, we investigate the land surface $\mathrm{CO}_{2}$ fluxes derived from a satellite-driven productivity model (TURC, Ruimy et al., 1996a) over Western Eurasia. The main objectives are twofold. Firstly, to evaluate the consistency of simulated $\mathrm{CO}_{2}$ fluxes and atmospheric model forcings (ECMWF analysis; REMO model) using site measurements. These flux simulations are used as boundary conditions in companion studies (Chevillard et al., 2002; Kjellström et al., 2002). Secondly, to characterize the temporal and spatial variability of the $\mathrm{CO}_{2}$ fluxes over continental mid-to-high latitudes, with a focus on the synoptic scale and the day-to-day variability. As opposed to the diurnal and seasonal cycles, which have been extensively described by tower-based data (for instance Malhi et al., 1999), spatial patterns of the day-today anomalies have received less attention, although they may significantly affect $\mathrm{CO}_{2}$ concentration over continents. This paper is organized as follows. Section 2 presents the TURC model and the modifications resulting from an assessment of recent flux data over boreal biomes. Section 3 presents the evaluation of the forcings and model results with local data from two sites in Russia and characterizes the spatial and temporal variability of daily $\mathrm{CO}_{2}$ fluxes over the continent. Conclusions and perspectives are given in Section 4.

\section{Data and models}

\subsection{The TURC model}

The TURC model (Ruimy et al., 1996a) is a production efficiency model which computes net primary productivity (NPP) as the difference between carbon uptake by vegetation (or gross primary production GPP) and carbon release by autotrophic respiration. This model uses meteorological forcings (air temperature, incoming solar radiation), together with satellite observations (Normalized Difference Vegetation Index, NDVI), and a map of ecosystem biomass. Daily GPP is calculated as the product of absorbed photosynthetically active radiation (APAR) by a conversion efficiency factor $\varepsilon$. This factor was derived from a compilation of experimental $\mathrm{CO}_{2}$ flux measurements over closed canopies and was initially assumed constant for all ecosystem types ( $\varepsilon=4.04 \mathrm{gCO}_{2} / \mathrm{MJ}$ APAR) (Ruimy et al., 1995; Ruimy et al., 1996a,b). The fraction of PAR absorbed by vegetation (fAPAR) is derived from NDVI using a linear relationship. PAR is a constant fraction (0.48) of incoming global solar radiation, supplied in this study by atmospheric circulation models. Autotrophic respiration is the sum of maintenance and growth respiration, which are computed separately. For the maintenance respiration, different plant organs are distinguished: leaves, fine roots and wood. Using experimental data, an average maintenance coefficient at $20{ }^{\circ} \mathrm{C}$ has been determined for each organ. Maintenance respiration is then scaled as a linear function of temperature and organ biomass. The Olson vegetation map (Olson et al., 1985) gives the total biomass for each grid cell. Leaf biomass is derived from NDVI data, fine root biomass is assumed equal to leaf biomass, and woody biomass is calculated as the remainder. Growth respiration is taken as a constant fraction (0.28) of GPP minus maintenance respiration (see Ruimy et al., 1996a for details).

The TURC model belongs to the Production Efficiency Model (PEM) family. Its main originality is to relate light absorption to GPP rather to NPP, and to derive parameters from $\mathrm{CO}_{2}$ exchange measurement (canopy fluxes for photosynthesis, chamber measurements for respiration parameter). During the Potsdam NPP model intercomparison study (Cramer et al., 1999), the original Light Use Efficiency (LUE) of TURC was among the highest values (Ruimy et al., 1999). 
Heterotrophic respiration is related to soil temperature through a $Q_{10}$ relationship $\left(Q_{10}=2\right)$. Soil moisture impact on decomposition rate follows the CENTURY model (Parton et al., 1993). For every grid cell, heterotrophic respiration is assumed to be equal to annual NPP (i.e. the net $\mathrm{CO}_{2}$ flux is null on an annual basis). This is an important hypothesis that allows the scaling of the heterotrophic respiration to realistic levels with regard to NPP (NPP being the main determinant of respiration; Janssens et al., 2001), but restricts the analysis to seasonal or shorter time scales. For consistency reasons, the TURC simulations use the same meteorological forcings as two companion studies, focused on atmospheric transport of $\mathrm{CO}_{2}$ (Chevillard et al., 2002; Kjellström et al., 2002), resulting in two TURC runs. The first is based on a global data set from ECMWF analysis, at a $1^{\circ} \times 1^{\circ}$ resolution. The second uses computations of meteorological forcings by the REMO regional atmospheric model at a $0.5^{\circ} \times 0.5^{\circ}$ resolution.

\subsection{Analysis of recent $\mathrm{CO}_{2}$ flux data over boreal and wetland ecosystems and TURC model update}

The conversion efficiency parameter $(\varepsilon)$ used in the original TURC model has been calibrated using a compilation of $\mathrm{CO}_{2}$ flux measurements over closed canopies (Ruimy et al., 1996a). At that time, most data were acquired over crops and temperate forests, and very few values were available for boreal ecosystems. There is growing evidence that boreal ecosystems have a rather low photosynthetic capacity compared to their temperate and tropical counterparts (e.g. Malhi et al., 1999). Gower et al. (1999) found a mean light use efficiency of $0.34 \mathrm{gDM} / \mathrm{MJ}_{\mathrm{ipar}}$ (based on above-ground NPP) for boreal evergreen, whereas the original TURC model leads to a higher value, of the order of 0.6. To quantify this effect, we conducted a literature review to compile measurements of maximum $\mathrm{CO}_{2}$ fluxes during clear summer days for boreal and temperate forests covering a wide range of climatic conditions. The maximum fluxes were obtained either by taking the upper $99 \%$ bin of the histogram of semi-hourly flux data (when long time-series were available) or by averaging six consecutive semi-hourly data from selected clear days (for studies presenting limited datasets).

Table 1 clearly shows a wide range of maximum $\mathrm{CO}_{2}$ fluxes, ranging from $-4.0 \mu \mathrm{mol} \mathrm{m} \mathrm{m}^{-2} \mathrm{~s}^{-1}$ for a larch forest in eastern Siberia to -29.0 for a broadleaved deciduous forest in North America. As opposed to incoming PAR during the peak growing season,
fAPAR was significantly different between the sites, with values ranging from 0.90 to 0.56 (Table 1 ). Therefore, the flux values $\left[\mathrm{FCO}_{2}\right]$ were normalized to a standard fAPAR of 0.95 , which is typical of a closed canopy temperate forest. This produces potential $\mathrm{CO}_{2}$ flux capacities, $\mathrm{FCO}_{2}^{*}$ calculated as:

$$
F \mathrm{CO}_{2}^{*}=F \mathrm{CO}_{2} \times 0.95 / \mathrm{fAPAR}
$$

which allow direct comparison between sites irrespective of LAI and light capture. The differences in maximum $\mathrm{CO}_{2}$ fluxes are slightly reduced when the fluxes are normalized by fAPAR, with boreal biomes showing lower flux capacities. This confirms that the conversion efficiency is intrinsically lower for boreal forests than for temperate forests, which is in agreement with the idea that boreal forests are nutrientlimited (Malhi et al., 1999). Figure 1 shows the normalized maximum $\mathrm{CO}_{2}$ flux as a function of mean annual temperature (hereafter MAT), and displays a strong linear relationship $\left(r^{2}=0.80, n=18, p<0.0001\right)$. The correlation may be interpreted as the result of a correlation between annual temperature and nutrient availability, and the annual mean temperature may be seen as a proxy, rather than a direct mechanism. It is likely that this relationship no longer persists for warmer temperature, because of an increasing importance of water stress. Low $\mathrm{CO}_{2}$ capacities have also been measured for arctic tundra (Williams et al., 2001; Zamolodchikov and Karelin, 2001 among others), which is in line with our findings. Such a strong relationship was not observed in some previous studies, mostly because this trend is a large-scale pattern and requires, to be observed, a sufficient range of annual mean temperature $\left(20^{\circ} \mathrm{C}\right.$ of amplitude here $)$. The scattering (Fig. 1) was small and partly explained by forest type (e.g. BOREAS sites), stand age and site quality (Buchmann et al., 1999). Given the dispersion, the smaller temperature range of $11.2^{\circ} \mathrm{C}$ for the EUROFLUX analyses (Valentini et al., 2000) obscured the GPP/temperature relationship, as pointed out by Janssens et al. (2001). Interestingly, the American sites and the Eurasian sites obey the same relationship (test of heterogeneity of slopes, $F=0.73$, not significant), which is no longer the case when latitude is used instead of MAT (Jarvis et al., 2001). Another advantage of using MAT is that the boreal zones exhibit strong continental gradients, for instance from Western Europe to Central Siberia, along which the $\mathrm{CO}_{2}$ flux capacity decreases, irrespectively of latitude. 
Table 1. Maximum $\mathrm{CO}_{2}$ fluxes for different sites of temperate and boreal forest ${ }^{\mathrm{a}}$

\begin{tabular}{|c|c|c|c|c|c|c|c|}
\hline Site name & Position & Species & $\begin{array}{c}\mathrm{FCO}_{2} \\
(\mu \mathrm{mol} \\
\left.\mathrm{m}^{-2} \mathrm{~s}^{-1}\right)\end{array}$ & $\begin{array}{c}F \mathrm{CO}_{2}^{*} \\
\left(\mu \mathrm{mol} \mathrm{m}^{-2} \mathrm{~s}^{-1}\right) \\
\text { with fAPAR } \\
\text { normalisation })\end{array}$ & $\begin{array}{l}\text { fPAR, } \\
\text { or LAI } \\
(-)\end{array}$ & $\begin{array}{c}\text { Mean } \\
\text { annual air } \\
\text { temperature } \\
\left({ }^{\circ} \mathrm{C}\right)\end{array}$ & Reference \\
\hline Yakutsk & $60^{\circ} \mathrm{N} 128^{\circ} \mathrm{E}$ & Larch & -4 & -5.8 & $\mathrm{LAI}=2$ & -9.6 & $\begin{array}{l}\text { Hollinger } \\
\quad \text { et al., } 1998\end{array}$ \\
\hline Labrador & $56^{\circ} \mathrm{N} 68^{\circ} \mathrm{W}$ & Spruce & -8 & -12.7 & 0.65 (b.e.) & -4.9 & $\begin{array}{c}\text { Fan et al., } \\
1995\end{array}$ \\
\hline $\mathrm{BN}-\mathrm{OBS}$ & $56^{\circ} \mathrm{N} 98^{\circ} \mathrm{W}$ & Black spruce & -10 & -11.2 & 0.86 & -2.9 & $\begin{array}{l}\text { Goulden } \\
\quad \text { et al., } 1997\end{array}$ \\
\hline BN-YJP & $54^{\circ} \mathrm{N} 105^{\circ} \mathrm{W}$ & Jack pine & -9 & -13.2 & 0.65 & -2.9 & $\begin{array}{l}\text { Joiner et al., } \\
1999\end{array}$ \\
\hline $\mathrm{BN}-\mathrm{OJP}$ & $56^{\circ} \mathrm{N} 99^{\circ} \mathrm{W}$ & Jack pine & -5.5 & -6.9 & 0.76 & -2.9 & $\begin{array}{l}\text { Fitzjarrald, } \\
2000\end{array}$ \\
\hline BS-OBS & $54^{\circ} \mathrm{N} 105^{\circ} \mathrm{W}$ & Black spruce & -10 & -11.2 & 0.85 & 1 & $\begin{array}{c}\text { Jarvis et al., } \\
1997\end{array}$ \\
\hline BS-YJP & $55^{\circ} \mathrm{N} 105^{\circ} \mathrm{W}$ & Jack pine & -10.2 & -14 & 0.69 & 1 & $\begin{array}{l}\text { McCaughey } \\
\text { et al., } 1997\end{array}$ \\
\hline BS-OA & $54^{\circ} \mathrm{N} 106^{\circ} \mathrm{W}$ & Aspen & -20 & -20 & 0.9 & 1 & $\begin{array}{l}\text { Grant et al., } \\
1999\end{array}$ \\
\hline BS-OJP & $55^{\circ} \mathrm{N} 105^{\circ} \mathrm{W}$ & Jack pine & -8 & -9.7 & 0.78 & 1 & $\begin{array}{l}\text { Baldocchi } \\
\text { et al., } 1997\end{array}$ \\
\hline $\begin{array}{l}\text { Hyytalia } \\
\text { (HY97) }\end{array}$ & $61^{\circ} \mathrm{N} 24^{\circ} \mathrm{E}$ & Scot pine & -15 & -16.5 & $\mathrm{LAI}=4$ & 3.2 & $\begin{array}{l}\text { Markkanen } \\
\quad \text { et al., 2001 }\end{array}$ \\
\hline NOPEX & $61^{\circ} \mathrm{N} 17^{\circ} \mathrm{E}$ & Spruce/pine & -15.5 & -17.3 & 0.85 (b.e.) & 5.5 & $\begin{array}{l}\text { Constantin } \\
\text { et al., } 1999\end{array}$ \\
\hline $\begin{array}{l}\text { Howland } \\
\text { (HL96) }\end{array}$ & $45^{\circ} \mathrm{N} 68^{\circ} \mathrm{E}$ & Spruce hemlock & -17 & -19 & 0.85 (b.e.) & 6.1 & $\begin{array}{l}\text { Hollinger } \\
\quad \text { et al., } 1999^{\mathrm{b}}\end{array}$ \\
\hline $\begin{array}{l}\text { Vielsalm } \\
\text { (VB97) }\end{array}$ & $50^{\circ} \mathrm{N} 6 . \mathrm{E}$ & $\begin{array}{l}\text { Mixed forest } \\
\text { - beech }\end{array}$ & -18 & -19.3 & $\mathrm{LAI}=4.5$ & 7.4 & $\begin{array}{l}\text { Aubinet } \\
\quad \text { et al., 2001 }\end{array}$ \\
\hline $\begin{array}{l}\text { Soroe } \\
\quad \text { (SO97) }\end{array}$ & $55^{\circ} \mathrm{N} 11^{\circ} \mathrm{E}$ & European beech & -21 & -22.3 & $\mathrm{LAI}=4.75$ & 8.1 & $\begin{array}{l}\text { Pilegaard } \\
\quad \text { et al., } 2000^{\mathrm{b}}\end{array}$ \\
\hline Harvard forest & $42^{\circ} \mathrm{N} 72^{\circ} \mathrm{W}$ & $\begin{array}{l}\text { Red oak/red } \\
\text { maple }\end{array}$ & -22 & -25.5 & $\mathrm{LAI}=3.4$ & 8.5 & $\begin{array}{l}\text { Goulden } \\
\quad \text { et al., } 1996\end{array}$ \\
\hline $\begin{array}{r}\text { Braschaat } \\
\text { (BR97) }\end{array}$ & $51^{\circ} \mathrm{N} 4^{\circ} \mathrm{E}$ & Scot pine, oaks & -16 & -18.9 & $\mathrm{LAI}=3.1$ & 10.2 & $\begin{array}{l}\text { Kowalski } \\
\quad \text { et al., } 2000^{\mathrm{b}}\end{array}$ \\
\hline $\begin{array}{l}\text { Landes } \\
\text { (Bray) }\end{array}$ & $44^{\circ} \mathrm{N} 0^{\circ} \mathrm{E}$ & Maritime pine & -26 & -27.4 & 0.85 & 12.5 & $\begin{array}{l}\text { Berbigier } \\
\quad \text { et al., } 2001\end{array}$ \\
\hline $\begin{array}{l}\text { Walker Branch } \\
\text { (WB98) }\end{array}$ & $36^{\circ} \mathrm{N} 84^{\circ} \mathrm{W}$ & $\begin{array}{l}\text { Dec. broad } \\
\text { leaved }\end{array}$ & -29 & -29.8 & $\mathrm{LAI}=6$ & 14.5 & $\begin{array}{l}\text { Baldocchi } \\
\quad \text { et al. } 2000^{\mathrm{b}}\end{array}$ \\
\hline Zotino & $61^{\circ} \mathrm{N} 89^{\circ} \mathrm{E}$ & Pine & -9 & -12.2 & 0.70 & -1.5 & $\begin{array}{l}\text { Shibistova } \\
\text { et al., } 2001\end{array}$ \\
\hline Fyodorovskoye & $56^{\circ} \mathrm{N} 33^{\circ} \mathrm{E}$ & Spruce & -13 & -14.5 & 0.85 & 3.8 & $\begin{array}{l}\text { Milukova } \\
\text { et al., } 2002\end{array}$ \\
\hline
\end{tabular}

${ }^{a}$ BN is for BOREAS Northern supersite, BS is for BOREAS Southern supersite. For BOREAS sites, fAPAR values follow Chen et al. (1997) and Chen (1996). When only Leaf Area Index (LAI) values were available, fAPAR was estimated with the following formula:

fAPAR $=0.95 \times[1-\exp (-0.6 \times \mathrm{LAI})]$.

(b.e.) is for a best estimate, based on qualitative site description, like 'closed conifer canopy'.

${ }^{b}$ Long-term measurements from FLUXNET database. 


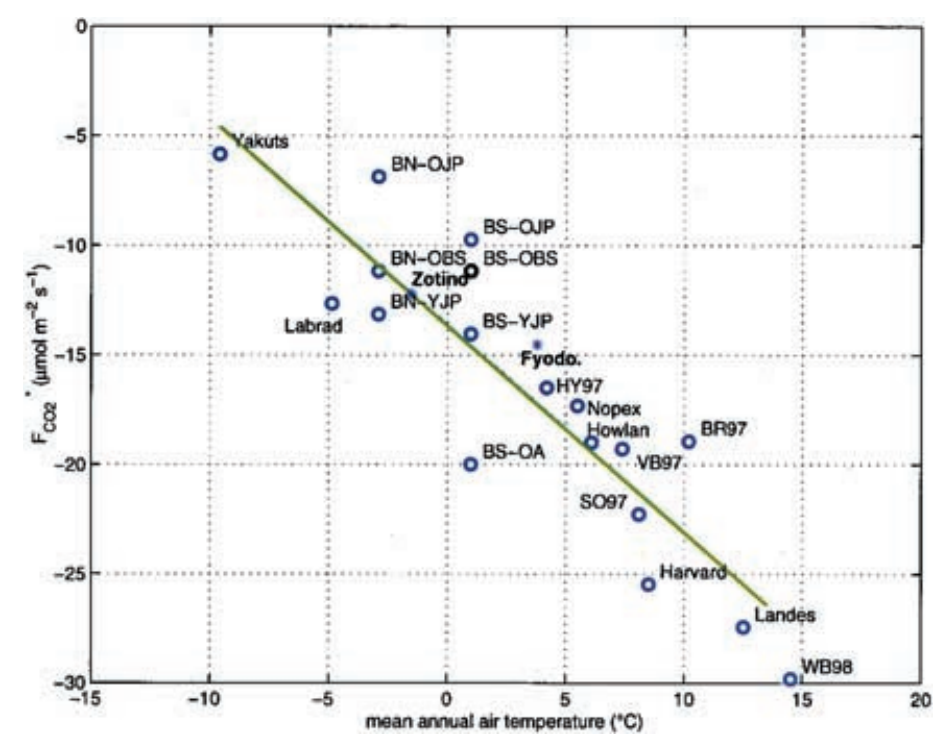

Fig. 1. Canopy $\mathrm{CO}_{2}$ fluxes capacity (see text) versus mean annual temperature over boreal and temperate forests (Table 1). Fluxes are normalized to an fPAR value of 0.95 . The equation of fit is $y=-0.9461 x-13.67\left(r^{2}=0.80, \mathrm{RMSE}=2.89, n=\right.$ $18, p<0.0001)$. Zotino and Fyodorovskoye sites $(*)$ are not used to calculate the regression.

With a subset of eight sites, for which daily lightuse efficiency (LUE) calculations were possible, we found a clear relationship between LUE and $\mathrm{FCO}_{2}^{*}$ $\left(N=8 ; r^{2}=0.92 ; p<0.01\right)$. This confirms that the both parameters reflect the photosynthetic capacity of an ecosystem. This subset also presents a clear relationship between LUE and MAT $\left(N=8 ; r^{2}=\right.$ $0.67 ; p<0.1)$. Given the strong links between daily LUE and $\mathrm{FCO}_{2}^{*}$, and the much larger dataset and temperature range for $\mathrm{FCO}_{2}^{*}$, we preferred to use the slope of the $\mathrm{FCO}_{2}^{*} / \mathrm{MAT}$ relationship to simulate a reduction of GPP from temperate to boreal and Arctic zones. The light use efficiency of the TURC model was reduced according to MAT (Legates and Willmott, 1990). We assumed that the maximum efficiency (TURC original value) is valid for temperate ecosystems $\left(\mathrm{MAT}=13.5^{\circ} \mathrm{C}\right.$ ). The temperaturedependent epsilon $(\varepsilon)$ is calculate as follows

$$
\begin{aligned}
& \text { if MAT }>13.5{ }^{\circ} \mathrm{C}, \varepsilon=0.02 \mathrm{~mol}[\mathrm{C}] / \mathrm{mol}_{\mathrm{APAR}} \\
& \text { if }-9.6<\mathrm{MAT}<13.5{ }^{\circ} \mathrm{C}, \\
& \varepsilon=0.02 \times(0.0358 \times \mathrm{MAT}+0.5170)
\end{aligned}
$$

if MAT $<-9.6, \varepsilon=0.0035$

Note that two sites (Fyodorovskoye and Zotino) are not included in this analysis, as they are part of the
Eurosiberian Carbonflux project and are used for model evaluation in the next sections.

Similarly, Frolking et al. (1998) compiled light use efficiency values for 13 wetland ecosystems (highlatitude bogs and fens) and concluded that the average light use efficiency was half of the value used in the original TURC model. Therefore, this measured mean value was used in the TURC model for boreal wetlands. For each pixel, the wetland fraction is derived from Cogley (1994), and the conversion efficiency is computed as the weighted mean of the wetland light use efficiency and the temperature-dependent efficiency described above. As these light use efficiency reductions reflect reductions in overall plant functioning and/or nutrient status, the autotrophic respiration was reduced in the same proportions.

Finally, a frost stress on photosynthesis has also been included, as it is commonly observed in boreal forests (e.g. Bergh and Linder, 1999). This effect is taken into account by reducing the conversion efficiency by $50 \%$ during the three days following a severe frost, defined by a daily mean air temperature lower than $-2{ }^{\circ} \mathrm{C}$.

In this paper the TURC model refers to the model version including the "temperature dependent efficiency", "wetland" and "frost" parametrizations. 
Table 2. Coefficient of determination $\left(r^{2}\right)$ between daily local measurements at the two sites and REMO and ECMWF outputs

\begin{tabular}{llllll}
\hline \multirow{2}{*}{$\mathrm{r}^{2}$} & & \multicolumn{2}{c}{ REMO model } & & \multicolumn{2}{c}{ ECMWF model } \\
\cline { 3 - 5 } & & Fyodorovskoye & Zotino & & Fyodorovskoye \\
\hline Air temperature & Forest & 0.73 & 0.80 & 0.95 & 0.97 \\
& Bog & 0.47 & 0.78 & 0.69 & 0.97 \\
Soil temperature & Forest & 0.74 & 0.90 & 0.84 & 0.41 \\
& Bog & 0.43 & 0.48 & 0.82 & 0.79 \\
& Forest & 0.48 & 0.34 & 0.75 & 0.75 \\
\hline
\end{tabular}

\subsection{Input data}

2.3.1. NDVI. The TURC model is driven by NDVI (Normalized Difference Vegetation Index) from the VEGETATION sensor on-board SPOT4 satellite. Since April 1998, VEGETATION provides a daily coverage of the earth with a $1 \mathrm{~km}$ resolution in the visible spectrum. The NDVI product used here is the so-called 'S product' from VITO centre, which is a 10-d maximum NDVI synthesis at $4 \mathrm{~km}$ resolution. This temporal and spatial sampling discards most of the cloudy pixels. The NDVI time profiles were filtered with the BISE method on a pixel basis (Viovy et al., 1992) and re-gridded to a $1^{\circ}$ latitude-longitude grid and the REMO grid (polarstereographic, $0.5^{\circ}$ resolution). This gave a clear signal in most areas other than moist tropical areas, which required a specific processing.

2.3.2. Meteorological forcings. Two sets of meteorological forcings are used to drive the TURC model. The first one consists of $\mathrm{ECMWF}^{1}$ data, whereas the second consists of REMO data (the REMO model is derived from the German weather forecast model). The ECMWF data are part of the "first guess" fields which consists of a series of 6-h forecasts after the assimilation cycle. The first guess fields of downward solar radiation, air temperature, soil temperature (first soil level, 0-7 cm) and soil wetness were averaged to obtain daily values. The REMO model (Karstens et al., 1996) is an atmospheric regional model with an online transport module and high vertical and horizontal spatial resolution. The REMO model was run over the Western Eurasia domain for 1998, with the ECMWF dataset as boundary conditions. Given the large size of the domain (between $40^{\circ} \mathrm{N}$ to $90^{\circ} \mathrm{N}$ in latitude and

\footnotetext{
${ }^{1}$ European Centre for Medium-Range Weather Forecasts.
}

between $50^{\circ} \mathrm{W}$ to $120^{\circ} \mathrm{E}$ in longitude), the boundary conditions represent a weak constraint.

\section{Results}

The TURC model was run at the global scale with ECMWF from April 1998 to December 1999. In 1998, the estimated gross and net primary productivities are 150.19 and $64.03 \mathrm{Gt}[\mathrm{C}] \mathrm{yr}^{-1}$, respectively, and are within the range of common estimates (e.g. Cramer et al., 1999; Goetz et al., 2000). The values for 1999 are very similar $(\mathrm{GPP}=149.43 \mathrm{Gt}[\mathrm{C}]$, and $\mathrm{NPP}=65.61$ $\mathrm{Gt}[\mathrm{C}])$.

\subsection{Atmospheric forcings consistency}

The atmospheric forcings from ECMWF and REMO were compared with local measurements performed at the Fyodorovskoye $\left(56.46^{\circ} \mathrm{N}, 32.92^{\circ} \mathrm{E}\right)$ and Zotino sites $\left(60.75^{\circ} \mathrm{N}, 89.41^{\circ} \mathrm{E}\right)$. Meteorological data and eddy covariance fluxes have been measured over a forest and a bog at each sites (see Schulze et al., 2002 for site descriptions). Since the ECMWF and REMO atmospheric models have been extensively evaluated (i.e. Klein and Jakob, 1999), we focus here only on the variables that are important for computing $\mathrm{CO}_{2}$ fluxes.

The daily mean values of incoming solar radiation and air temperature from the ECMWF dataset agree very well with measurements on the two sites $\left(r^{2}>0.8\right.$, see Table 2). Soil temperature in the upper $7 \mathrm{~cm}$ layer presents a weaker agreement $\left(r^{2}=0.7\right.$ in Fyodorovskoye forest, $r^{2}=0.4$ in Zotino forest) but are still reasonable. ECMWF soil temperature estimates reach a very low value during winter (below $-20^{\circ} \mathrm{C}$ ) for both sites. Field measurements show that 
snow has a large insulation effect and that soil temperature never decreases below $-5{ }^{\circ} \mathrm{C}$. Soil temperatures that are too low, as estimated by the atmospheric model, lead to an underestimation of soil respiration fluxes during winter. In our case, moreover, since the fluxes are balanced over the whole year, underestimation of respiration during winter brings about an overestimation during summer of about $10-15 \%$ in absolute value. The accuracy of the soil water content estimated by the ECMWF model is also questionable: in non-arid areas, soil water content stays very close to field capacity for the whole year, and does not decrease even during summer.

Despite its finer grid resolution, the REMO simulation has a lower correlation with local measurements, especially for incoming solar radiation and air temperature. This is due to the lack of constraints by atmospheric observations in REMO model, compared to the data-rich ECMWF reanalysis. However, the REMO estimates of soil moisture do not exhibit the "wet" behavior of ECMWF simulations.

We conclude that the ECMWF forcings are consistent with the local data, except for the soil moisture and winter soil temperature. The simulation of these variables, and also their treatment during the dataassimilation process, might have to be reconsidered to properly address $\mathrm{CO}_{2}$ flux estimations. One major difference between the weather-forecast and the $\mathrm{CO}_{2}$ flux perspectives is that, in the first case, soil variables are seen as a way to obtain good energy fluxes for the atmosphere (and to match air temperature data), whereas they are per se important drivers of the $\mathrm{CO}_{2}$ cycle. The lower correlations obtained with REMO are explained by the fact that REMO generates its own climate and does not assimilate observations. Synoptic weather structures are frequently shifted in time and space, but the averages over a few days are more consistent with the in-situ measurements. For instance, on a weekly basis, the correlation between radiation or temperature and ground data exceeds 0.8 for the two sites.

\subsection{Comparison between $\mathrm{FCO}_{2}$ measurements and TURC model results}

Milyukova et al. (2002) and Kurbatova et al. (2002) present and analyse the ground-based measurements on the two Russian experimental sites, which are used hereafter. The footprint of eddy covariance systems is of the order of a few square kilometres, while simulations with the TURC model were performed over grid cells of $2500 \mathrm{~km}^{2}$ or more. At the very least the light capture (fAPAR) is different at these two scales, because of land use and land cover heterogeneity (SPOT4 data acquired on 22 April 1998, not shown); therefore, we do not expect the modeled fluxes to rigorously match the measurements. Nevertheless, we expect that the TURC model and the measured fluxes to exhibit similar temporal fluctuations, and reasonable correlations, since we can assume that weather conditions are more or less homogeneous over tens of kilometres over flat terrain.

The correlation between measured and estimated daily $\mathrm{FCO}_{2}$ are given in Table 3, for periods corresponding to the 1998 growing season (June-October) and the whole 1999 year. The TURC model driven by ECMWF explains $29-47 \%$ of the variance of the daily surface $\mathrm{FCO}_{2}$, which is satisfying for a global model driven by operationally available forcings and satellite data. The TURC simulations driven by ECMWF forcings are closer to the tower measurements than the REMO driven simulations. This is mainly due to the temporal inaccuracy of the REMO-simulated synoptic events, as mentioned before. The question then arises whether the unexplained variance can be attributed to the TURC model or to the forcings.

In order to investigate this point, we performed simulations using local weather data (PAR, soil temperature, and air temperature) when available, and atmospheric models data to fill any gaps. This analysis was restricted to the days when all these variables, including measured $\mathrm{CO}_{2}$ fluxes over both bog and forest, were available, leaving about $50 \mathrm{~d}$ for Fyodorovskoye and $70 \mathrm{~d}$ for Zotino in 1998 (231 and $135 \mathrm{~d}$, respectively, in 1999). The use of local environment forcings improved the TURC simulations significantly in most cases. This is obvious for REMO-driven simulations: $r^{2}$ rises from 0.04 to 0.57 for Zotino, and from 0.16 to 0.46 for Fyodorovskoye (Table 3, see also Fig. 2c). It is less important but still significant for the ECMWFdriven simulations, with $r^{2}>0.50$ (Table 3). The use of local forcings always decreases RMSE. The highest RMSE value $\left(2.29 \mathrm{gC} \mathrm{m}^{-2} \mathrm{~s}^{-1}\right)$ occur when TURC is driven by REMO data. Using ECMWF and local forcings results in RMSE of $0.76-1.22 \mathrm{gC} \mathrm{m}^{-2} \mathrm{~s}^{-1}$, which are similar to those found by Amthor et al. (2001; Table 6: RMSE between $0.75-1.07 \mathrm{gC} \mathrm{m}^{-2} \mathrm{~s}^{-1}$ ) during a comparison of nine models with tower measurements over a boreal forest.

Since the transport models used by companion studies require a description of the diurnal cycle as well, an interpolation scheme was designed to distribute the 
Table 3. Comparison between daily surface $\mathrm{CO}_{2}$ flux simulations and daily site measurements ${ }^{\mathrm{a}}$

\begin{tabular}{lrrrrr}
\hline & \multicolumn{3}{c}{ Fyodorovskoye site } & & RMSE \\
\cline { 2 - 5 } Weather forcing input & $N(\mathrm{~d})$ & $r^{2}$ & $\left(\mathrm{gC} \mathrm{m}^{-2} \mathrm{~d}^{-1}\right)$ & Slope & $\begin{array}{c}\text { Intercept } \\
\left(\mathrm{gC} \mathrm{m}^{-2} \mathrm{~d}^{-1}\right)\end{array}$ \\
\hline REMO 98 & 47 & 0.16 & 2.29 & 0.19 & -0.31 \\
ECMWF 98 & 47 & 0.44 & 1.27 & 0.37 & -0.11 \\
ECMWF 99 & 231 & 0.37 & 1.16 & 0.55 & -0.36 \\
Local data forcings 1998 (gaps filled by REMO) & 47 & 0.46 & 1.92 & 0.29 & -0.16 \\
Local data forcings 1998 (gaps filled by ECMWF) & 47 & 0.49 & 1.22 & 0.40 & -0.22 \\
Local data forcings 1999 (gaps filled by ECMWF) & 231 & 0.46 & 1.08 & 0.59 & -0.4 \\
& Zotino site & & & \\
REMO 98 & 67 & 0.04 & 1.31 & 0.23 & 0.10 \\
ECMWF 98 & 67 & 0.29 & 1.00 & 0.60 & 0.24 \\
ECMWF 99 & 135 & 0.47 & 0.81 & 0.63 & 0.21 \\
Local data forcings 1998 (gaps filled by REMO) & 67 & 0.57 & 0.94 & 0.97 & 0.71 \\
Local data forcings 1998 (gaps filled by ECMWF) & 67 & 0.58 & 0.85 & 0.97 & 0.57 \\
Local data forcings 1999 (gaps filled by ECMWF) & 135 & 0.51 & 0.76 & 0.63 & 0.18 \\
\hline
\end{tabular}

${ }^{a}$ At each site we weighted the fluxes from the forest and bog towers using the wetland ratio of the corresponding TURC grid cell.

$\mathrm{CO}_{2}$ fluxes over a $24 \mathrm{~h}$ period, in keeping with the basic assumptions of the TURC model (Chevillard et al., 2002). Briefly, GPP is distributed with the diumal cycle of radiation, and respirations are distributed with the cycle of temperature so that the daily means are kept. Thanks to the additional variability enforced by the diurnal cycle, the coefficients of determination between measured and simulated half-hourly $\mathrm{CO}_{2}$ fluxes rise to $r^{2}=0.65$ or more for both sites, which gives an indication of what can be expected from the TURC model forced by local forcings. There is still room for model improvement. Water stress caused by soil moisture depletion or high vapour pressure deficit (VPD) often reduces light use efficiency, and could be accounted for if accurate moisture forcings can be obtained. Overall, these different simulations show that, without any calibration and assuming a balance between NPP and heterotrophic respiration, the TURC model explains approximately half of the variance of the daily $\mathrm{FCO}_{2}$ data.

\subsection{Day-to-day variability}

A strong day-to-day variability of the net $\mathrm{CO}_{2}$ fluxes has already been described at the local scale on the basis of eddy covariance measurements (e.g. Baldocchi et al., 1997; Lindroth et al., 1998, among others). During the growing season, although vegetation is active, ecosystems may become a temporary source of $\mathrm{CO}_{2}$ on a $24 \mathrm{~h}$ average. This variability is mainly due to rapid changes in cloudiness. Clouds reduce insolation which in turn limits photosynthesis. At the same time, respiration, which is controlled by temperature and soil moisture, stays more or less constant at this time scale. Baldocchi et al. (2001b) carried out a spectral analysis on $5 \mathrm{yr}$ of eddy flux measurements over a temperate deciduous forest and found a spectral peak for period of $3.7 \mathrm{~d}$, which they associated with "the passage of weather fronts". As far as we know, the occurrence of such fluctuations has not been documented at the continental scale.

The high temporal resolution of the TURC simulations, compared to many carbon cycle models (Cramer et al., 1999), allows such an investigation. Figure 2 presents a typical example of the day-to-day variability of surface $\mathrm{CO}_{2}$ fluxes, as seen at the site-scale. Measurements acquired over the Fyodorovskoye forest during the beginning of August 1998 are displayed together with the outputs of the atmospheric models for the corresponding grid cell (Figs. 2a and b). As expected, ECMWF incoming radiation (Fig. 2b) matches the local data very well, but REMO does not (Fig. 2a). Comparison with METEOSAT images confirms that the clouds are mis-localized by the REMO model (not shown) but accurately simulated by ECMWF (Fig. 3). Fig. $2 \mathrm{c}$ and $\mathrm{d}$ also presents the observed and modelled surface $\mathrm{CO}_{2}$ fluxes for the same period. The $\mathrm{CO}_{2}$ fluxes shift from a source (before 12 August) to a sink (after 12 August) and mirror the incoming radiation curve. The ECMWF-driven TURC simulation reproduces this pattern (Fig. 2d), as well as the TURC simulation driven by local forcings (Fig. 2c). 


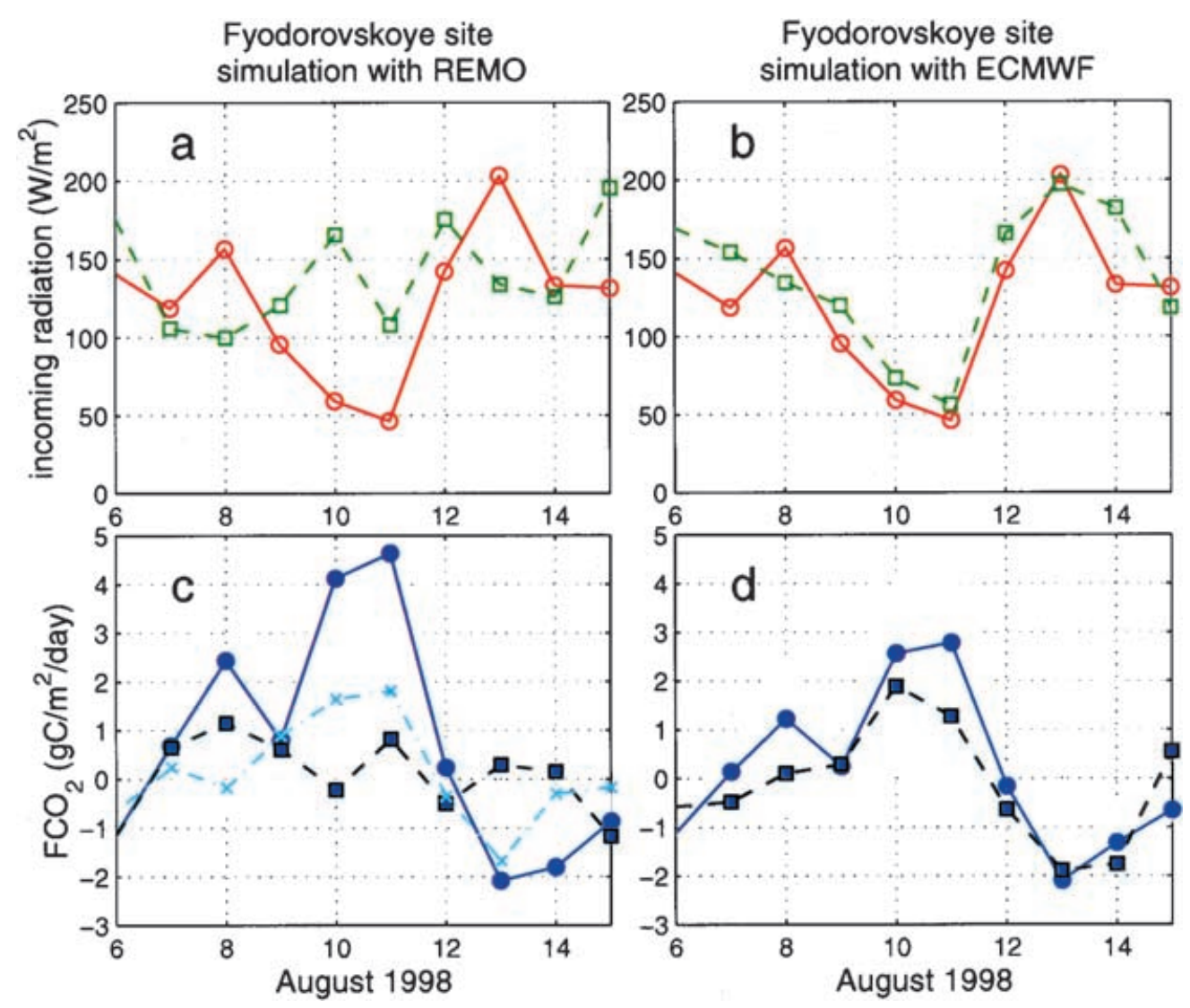

Fig. 2. (a, b) Incoming solar radiation from REMO and ECMWF forcings ( $\square$ ), respectively, along with measurements (O) over the Fyodorovskoye forest site between 6 and 15 August 1998. (c) $\mathrm{CO}_{2}$ fluxes from the TURC model driven by REMO (ロ) and local forcings $(\times)$. The shaded zone is the envelope of the $\mathrm{CO}_{2}$ fluxes measurement over forest (highest value) and bog (lowest value). Circles ( ) represent a composite of forest and bog fluxes weighted by the wetland fraction of the

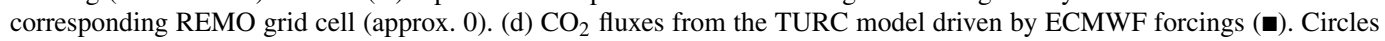
(•) represent a composite of forest and bog fluxes weighted by the wetland fraction of the corresponding ECMWF grid cell (approx. 0.38) (different resolution and different projection). Both simulation and measurement display a switch from $\mathrm{CO}_{2}$ source to $\mathrm{CO}_{2}$ sink on 12 August corresponding to incoming radiation.

In this example, the rate of change is relatively slow because of the slow motion of clouds, but it can be much quicker. The spatial extent of this event is shown on Fig. 3. This figure presents maps of daily $\mathrm{CO}_{2}$ fluxes simulated by TURC (ECMWF forcings) along with ECMWF surface incoming radiation and corresponding METEOSAT images for the same days. The daily fluxes simulated by TURC over western Eurasia display clear patterns of $\mathrm{CO}_{2}$ sinks and sources, generally ranging from an uptake of $4 \mathrm{gC} \mathrm{m}^{-2} \mathrm{~d}^{-1}$ to a release of $2.5 \mathrm{gC} \mathrm{m}^{-2} \mathrm{~d}^{-1}$. An analysis of the TURC simulations showed that the primary driver of these patterns is the surface incoming radiation (Fig. 3, left column), which is due to optically-thick cloud ensembles, as indicated by the METEOSAT images. As a result, the source areas simulated by TURC-ECMWF clearly match the cloudy areas identified on the visible METEOSAT images. During these $5 \mathrm{~d}$, cloudy air masses moved over the Fyodorovskoye site, resulting in strong temporal fluctuations of the surface fluxes. The variability of the daily $\mathrm{CO}_{2}$ flux observed at the tower scale (Fig. 2, shift from source to sink) is the local perception of a larger synoptic-scale picture (Fig. 3, movement of source and sink patterns). 

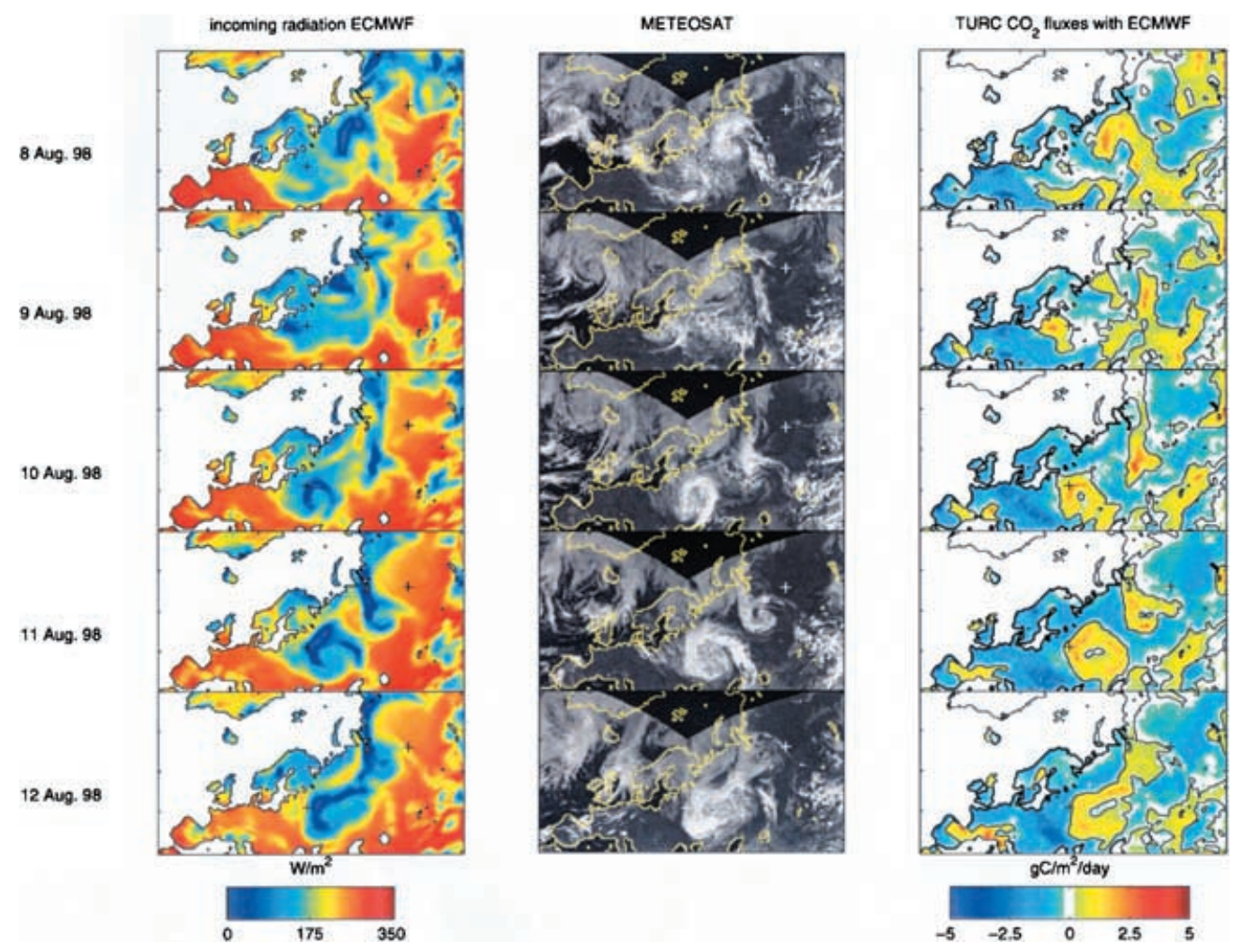

Fig. 3. Sequence of $5 \mathrm{~d}$ over the Eurosiberian domain (REMO grid, polar stereographic projection). Left column: ECMWF surface incoming radiation. Middle column: composite visible image from METEOSAT satellites at $0^{\circ}$ and $63{ }^{\circ} \mathrm{E}$ longitude at 12 UTC. Right column: daily $\mathrm{CO}_{2}$ flux maps from TURC driven by ECMWF forcings. Fluxes are negative for ecosystems' $\mathrm{CO}_{2}$ uptake. Isolines represent null fluxes. The two crosses are for the measurement sites (West, Fyodorovskoye; East, Zotino). These maps show that the spatial patterns of the daily $\mathrm{CO}_{2}$ fluxes correspond to cloud ensembles.

To establish the robustness of this modelling-based result, we performed a sensitivity study focused on model assumptions. It has been recognized that the daily maximum $\mathrm{CO}_{2}$ uptake may occur during slightly overcast days (Gu et al., 1999; Goulden et al., 1997; Baldocchi and Vogel, 1995), which typically have a high level of diffuse radiation. This in turn may lead to a better distribution of light within the canopy, and a better efficiency of leaf-level photosynthesis. Such conditions may also correspond to lower VPD (Freedman et al., 2001), which is important for some plant types. These effects may be overlooked in TURC simulations, as it uses a linear relationship between daily photosynthesis and daily absorbed PAR. This could lead to an underestimation of photosynthesis during cloudy days, and exaggerate the contrast between source and sink patterns. We made a sensitivity test by modifying the form of the light/photosynthesis response. Following Gu et al. (1999), photosynthesis was enhanced by $40 \%$ for daily mean insolation corresponding to high diffuse radiation (taken as days with intermediate radiation level). This simulation resulted in slightly smoothed $\mathrm{CO}_{2}$ fluxes, but still revealed large daily sink and source areas corresponding to cloud ensembles.

The patchy structure of the daily $\mathrm{CO}_{2}$ fluxes, described in Fig. 3 on a few particular days, occurs every day during the vegetation period over Eurasia. This shows that the domain is never totally a sink of $\mathrm{CO}_{2}$ even during the peak growing season. Figure 4 shows the distribution as a function of time of the relative sink and source areas for the whole domain. The sink area increases from April to June and then decreases until the end of October. For any day around the 


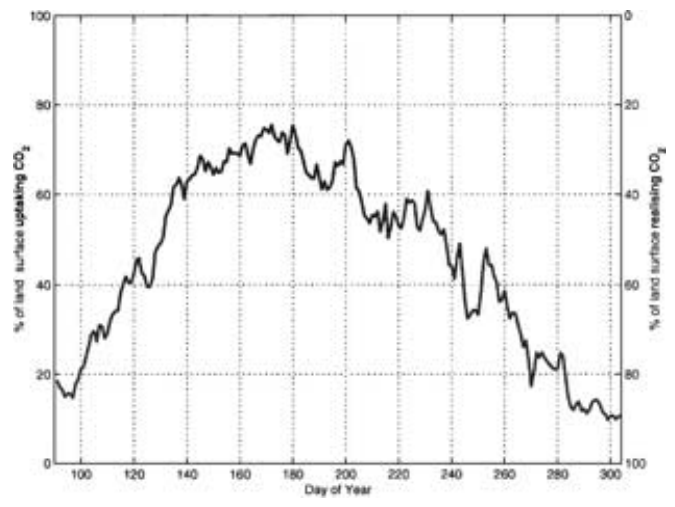

Fig. 4. Time evolution of the fraction of land surface fixing (left axis) or releasing (right axis) $\mathrm{CO}_{2}$ over Western Eurasia (see map in Fig. 3) simulated by TURC model using REMO forcings.

maximum of the vegetation period (June) no more than $80 \%$ of the land is taking up carbon. Similar statistics were found with the REMO and ECMWF forcings. Figure 4 also presents a significant day-to-day variability: $10 \%$ of the domain area can shift from sink to source within only $2 \mathrm{~d}$ (for instance, see days 200 and 243).

The importance of such spatial and temporal dynamics of surface fluxes for atmospheric transport are still to be investigated. Front passages, for instance, generate specific atmospheric transport, which may include transport from boundary layer to upper troposphere, e.g. Bethan et al. (1998) and references therein. More generally, over continents, large areas of optically-thick clouds causing a temporary source of surface $\mathrm{CO}_{2}$ correspond to different synoptic situations and atmospheric mixings. The net effect on $\mathrm{CO}_{2}$ transport and $\mathrm{CO}_{2}$ concentrations deserves further investigation. The surface $\mathrm{CO}_{2}$ fluxes simulated by the TURC model are currently fed into atmospheric transport models: the REMO model (Chevillard et al., 2002) which has an on-line transport module, the TM3 model (Heimann et al., unpublished) and the MATCH model (Kjellström et al., 2002), which use ECMWF wind fields. The comparison with $\mathrm{CO}_{2}$ profiles from aircraft data allows the evaluation of both $\mathrm{CO}_{2}$ fluxes and transport and the quantification of their interactions.

\section{Conclusion}

This article aimed at characterizing the spatial and temporal patterns of surface $\mathrm{CO}_{2}$ fluxes over Eurasia. We first presented an analysis of recent $\mathrm{CO}_{2}$ flux measurements over temperate and boreal forests. A strong linear relationship was found between maximum instantaneous $\mathrm{CO}_{2}$ fluxes and the mean annual air temperature, showing that boreal biomes have a lower photosynthetic capacity than temperate ecosystems. This effect is consistent with the idea that boreal biomes are more nutrient-limited than their temperate counterparts. Based on this analysis and similar studies on boreal wetland, a new version of the TURC productivity model was developed and run for 1998 and 1999 over Eurasia, using NDVI from SPOT4-VEGETATION and climate forcings from the ECMWF and REMO models. Input consistency and $\mathrm{CO}_{2}$ flux accuracy were evaluated against local measurements from two sites in Russia. The spatial and temporal patterns of the simulated daily $\mathrm{CO}_{2}$ fluxes were then analysed. The daily $\mathrm{CO}_{2}$ fluxes displayed characteristic patterns of positive and negative fluxes even in the middle of the growing season. These patterns were found to correspond to cloudy areas, and to 'follow' the motion of cloud ensembles over the domain. Of particular interest is the possible correlation of the source/sink patterns, which corresponds to synoptic events, with the atmospheric transport. This question needs to be addressed, because it could lead to preferential mixing of $\mathrm{CO}_{2}$ depleted/enriched air.

\section{Acknowledgements}

We thank our partners from the Eurosiberian Carbonflux EU project, Eumetsat agency for the METEOSAT images and the CNES/VEGETATION program. ECMWF is acknowledged for providing the meteorological data through the MARS facility. We also would like to thank Erik Kjellstöm for his constructive comments, Steve Wright for his careful reading, and two anonymous reviewers who helped to improve this paper.

Further, we would like to thank all the teams that provide $\mathrm{CO}_{2}$ fluxes measurements, and the teams from FLUXNET who made them easily available. 


\section{REFERENCES}

Amthor, J. S., Chen, J. M., Clein, J. S., Frolking, S. E., Goulden, M. L., Grant, R. F., Kimball, J. S., King, A. W., McGuire, A. D., Nikolov, N. T., Potter, C. S., Wang, S. and Wofsy, S. C. 2001. Boreal forest $\mathrm{CO}_{2}$ exchange and evapotranspiration predicted by nine ecosystem process models: Inter-model comparisons and relationships to field measurements. J. Geophys. Res. 106, D24, 33623-33648.

Aubinet, M., Chermanne, B., Vandenhaute, M., Longdoz, B., Yernaux, M. and Laitat, E. 2001. Long term measurements of water vapour and carbon dioxide fluxes above a mixed forest in Ardenne's region. Agric. For. Meteorol. 108, 293 315.

Baldocchi, D. D. and Vogel, C. A. 1995. Energy and $\mathrm{CO}_{2}$ flux densities above and below a temperate broadleaved forest and boreal pine forest. Tree Physiol. 16, 516.

Baldocchi, D. D., Vogel, C. A. and Hall, B. 1997. Seasonal variation of carbon dioxide exchange rates above and below a boreal jack pine forest. Agric. For. Meteorol. 83, 147-170.

Baldocchi, D. D., Finnigan, J. J., Wilson, K. W., Paw, U., K. T. and Falge, E. 2000. On measuring net ecosystem carbon exchange in complex terrain over tall vegetation. Bound-lay. Meteorol. 96, 257-291.

Baldocchi, D. D., Falge, E., Gu, L., Olson, R., Hollinger, D., Running, S., Anthoni, P., Bernhofer, Ch., Davis, K., Fuentes, J., Goldstein, A., Katul, G., Law, B., Lee, X., Malhi, Y., Meyers, T., Munger, J. W., Oechel, W., Pilegaard, K., Schmid, H. P., Valentini, R., Verma, S., Vesala, T., Wilson, K. and Wofsy, S. 2001a. FLUXNET: a new tool to study the temporal and spatial variability of ecosystem-scale carbon dioxide, water vapor and energy flux densities. Bull. Am. Meteorol. Soc. 82, 24152435.

Baldocchi, D. D., Falge, E., and Wilson, K. 2001b. A spectral analysis of biosphere-atmosphere trace gas flux densities and meteorological variables across hour to year time scales. Agric. For. Meteorol. 107, 1-27.

Berbigier, P., Bonnefond, J. M. and Mellmann, P. 2001. $\mathrm{CO}_{2}$ and water vapour fluxes for 2 years above Euroflux forest site. Agric. For. Meteorol. 108, 3, 183-197.

Bergh, J. and Linder, S. 1999. Effects of soil warming during spring in photosynthetic recovery in boreal Norway spruce stands. Glob. Change Biol. 5, 245-253.

Bethan, S., Vaughan, G., Gerbig, C., Volz-Thomas, A., Richer, H. and Tiddeman, D. A. 1998. Chemical air mass differences near fronts. J. Geophys. Res. 103, D11, 1341313434.

Bousquet, P., Ciais, P., Peylin, P., Ramonet, M. and Monfray, P. 1999. Inverse modeling of annual atmospheric $\mathrm{CO}_{2}$ sources and sinks, 1, Method and control inversion. J. Geophys. Res. 104, D21, 26161-26178.

Bousquet, P., Peylin, P., Ciais, P., Le Quéré, C., Friedlingstein, P. and Tans, P. P. 2000. Regional changes in carbon dioxide fluxes of land and oceans since 1980. Science 290,, 5495, 1342-1346.
Buchmann, N. and Schulze, E.-D. 1999. Net $\mathrm{CO}_{2}$ and $\mathrm{H}_{2} \mathrm{O}$ fluxes of terrestrial ecosystems. Global Biogeochem. Cy. 13, 751-760.

Chen, J. M. 1996. Canopy architecture and remote sensing of the fraction of photosynthetically active radiation in boreal conifer stands. IEEE Trans. Geosci. Remote 34, 13531368.

Chen, J. M., Rich, P. M., Gower, S. T., Norman, J. M. and Plummer, S. 1997. Leaf area index of boreal forests: theory, techniques and measurements. J. Geophys. Res. BOREAS Special Issue, 102, D24, 29429-29444.

Chevillard, A., Karstens, U., Ciais, P., Lafont, S. and Heimann, M. 101. Simulation of atmospheric CO2 transport in Europe and Siberia using the regional scale model REMO. Tellus 54B, this issue.

Ciais, P., Tans, P. P., Trolier, M., White, J. W. C. and Francey, R. J. 1995. A large northern hemisphere terrestrial $\mathrm{CO}_{2}$ sink indicated by $13 \mathrm{C} / 12 \mathrm{C}$ ratio of atmospheric $\mathrm{CO}_{2}$. Science 269, 1098-1102.

Constantin, J., Grelle, A., Ibrom, A. and Morgenstern, K. 1999. Flux partitioning between understorey and overstorey in a boreal spruce/pine forest determined by the eddy covariance method Agric. For. Meteorol. 98-99, 629643.

Cramer, W., Kicklighter, D. W., Bondeau, A., Moore III, B., Churkina, G., Nemry, B., Ruimy, A., Schloss, A. and participants of the Potsdam NPP Model Intercomparison. 1999. Comparing global models of terrestrial net primary productivity (NPP): overview and key results. Glob. Change Biol. 5, Suppl. 1, 115.

Cogley, J. G. 1987. GGHYDRO - Global Hydrographic Data, Release 2.1 (ㄷ) J. G. Cogley 1987, 1991, 1994). Department of Geography, Trent University, Peterborough, Ontario, Canada.

Fan, S. M., Goulden, M. L., Munger, J. W., Daube, B. C., Bakwin, P. S., Wofsy, S. C., Amthor, J. S., Fitzjarrald, D. R., Moore, K. E. and Moore, T. R. 1995. Environmental controls on the photosynthesis and respiration of a boreal lichen woodland: a growing season of whole ecosystem exchange measurements by eddy covariance. Oecologia 102, 443-452.

Fan, S., Gloor, M., Mahlman, J., Pacala, S., Sarmiento, J., Takahashi, T. and Tans, P. 1998. A large terrestrial carbon sink in North America implied by atmospheric and oceanic carbon dioxide data and models. Science 282, 5388, 442446.

Fitzjarrald, D. R. 2000. BOREAS TF-08 NSA-OJP Tower Flux, Meteorological, and Soil Temperature Data. Available online at [http://www.daac.ornl.gov/] from the ORNL Distributed Active Archive Center, Oak Ridge National Laboratory, Oak Ridge, Tennessee, USA.

Freedman, J. M., Fitzjarrakd, D. R., Moore, K. E. and Sakai, R. K. 2001. Boundary layer clouds and vegetationatmosphere feedbacks. J. Climate 14, 180-196. 
Frolking, S., Bubier, J. L., Moore, T. R., Ball, T., Bellisario, L. M., Bhardwaj, A., Carroll, P., Crill, P. M., Lafleur, P. M., McCaughey, J. H., Roulet, N. T., Suyker, A. E., Verma, S. B., Waddington, M. J. and Whiting, G. J. 1998. Relationship between ecosystem productivity and photosynthetically-active radiation for northern peatlands. Global Biogeochem. Cy. 12, 115-126.

Goetz, S. J, Prince, S. D., Small, J., Gleason, A. and Thawley, M. M. 2000. Interannual variability in global terrestrial primary production: results of a model driven with satellite observations. J. Geophys. Res. 105, D15, 20077-20091.

Goulden, M. L., Munger, J. W., Fan, S.-M., Daube, B. C. and Wofsy, S. C. 1996. Measurements of carbon sequestration by long-term eddy covariance: methods and a critical evaluation of accuracy. Glob. Change Biol. 2, 169182.

Goulden, M. L., Daube, B. C., Fan, S.-M., Sutton, D. J., Bazzaz, A., Munger, J. W. and Wofsy, S. C. 1997. Physiological responses of a black spruce forest to weather $J$. Geophys. Res. 102, D24, 28987-28996.

Gower, S. T., Kucharik, C. J. and Norman, J. M. 1999. Direct and indirect estimation of leaf area index, fAPAR, and net primary production of terrestrial ecosystems. Remote Sens. Environ. 70, 1, 29-51.

Grant, R. F., Black, T. A., den Hartog, G., Berry, J. A., Neumann, H. H., Blanken, P. D., Yang, P. C., Russell, C. and Nalder., I. A. 1999. Diurnal and annual exchanges of mass and energy between an aspen-hazelnut forest and the atmosphere: testing the mathematical model Ecosys with data from the BOREAS experiment. J. Geophys. Res. 104, D22, 27699-27718.

Gu, L., Fuentes, J. D. and Shugart, H. H. 1999. Responses of net ecosystems exchanges of carbon dioxide to changes in cloudiness: results from two North American decidious forests. J. Geophys. Res. 104, D24, 31421-31434.

Hollinger, D. Y., Goltz, S. M., Davidson, E. A., Lee, J. T., Tu, K. and Valentine, H. T. 1999. Seasonal patterns and environmental control of carbon dioxide and water vapour exchange in an ecotonal boreal forest. Glob. Change Biol. 5, 891-902.

Hollinger, D. Y., Kelliher, F. M., Schulze, E.-D., Bauer, G., Arneth, A., Byers, J. N., Hunt, J. E., McSeveny, T. M., Kobak, K. I., Milukova, I., Sogachev, A., Tatarinov, F., Varlagin, A., Ziegler, W. and Vygodskaya, N. N. 1998. Forestatmosphere carbon dioxide exchange in eastern Siberia. Agric. For. Meteorol. 90, 291-306.

Janssens, I. A., Lankreijer, H., Metteucci, G., Kowalski, A. S., Buchmann, N., Epron, D., Pilegaard, K., Kutsch, W., Longdoz, B., Grünwald, T., Montagnani, L., Dore, S., Rebmann, C., Moors, E. J., Grelle, A., Rannik, Ü., Morgenstern, K., Clement, R., Gudmundsson, J., Minerbi, S., Berbigier, P., Ibrom, A., Moncrieff, J., Aubinet, M., Berhofer, C., Jensen, N. O., Vesala, T., Granier, A., Schulze, E.-D., Lindroth, A., Dolman, A. J., Jarvis, P. G., Ceulemans, R. and Valentini, R. 2001. Productivity and disturbance overshadow temperature in determining soil and ecosystem respiration across European forests. Global Change Biol. 7, 269-278.
Jarvis, P. G., Massheder, J. M., Hale, S. E., Moncrieff, J. G., Rayment, M., and Scott, S. L. 1997. Seasonal variation of carbon dioxide, water vapour and energy exchanges of a boreal black spruce forest J. Geophys. Res. BOREAS Special Issue, 102, D24, 28953-28966.

Jarvis, P. G., Dolman, A. J., Schulze, E.-D., Matteucci, G., Kowalski, A. S., Ceulemans, R., Rebmann, C., Moors, E. J., Granier, A., Gross, P., Jensen, N. O., Pilegaard, K., Lindroth, A., Grelle, A., Bernhofer, C., Grunwald, T., Aubinet, M., Vesala, T., Rannik, U., Berbigier, P., Loustau, D., Guomundson, J., Ibrom, A., Morgenstern, K., Clement, R., Moncrieff, J., Montagnani, L., Minerbi, S. and Valentini, R. 2001. Carbon balance gradient in European forests: should we doubt 'surprising' results? A reply to Piovesan \& Adams. J. Veg. Sci. 12, 145-150.

Joiner, D. W., McCaughey, J. H., Lafleur, P. M. and Bartlett., P. A. 1999. Water and carbon dioxide exchange at a boreal young jack pine forest in the BOREAS northern study area. J. Geophys. Res. 104, D22, 27641-27652.

Karstens, U., Nolte-Holube, R. and Rockel, B. 1996. Calculation of the water budget over the Baltic sea Catchment area using the regional forecast model REMO for June 1993. Tellus 48A, 684-692.

Kjellström, E., Holmén, K., Eneroth, K. and Engardt, M. 2002. Summertime Siberian $\mathrm{CO}_{2}$ simulations with a regional transport model: a feasibility study of carbon uptake calculations from EUROSIB data. Tellus 54B, this issue.

Klein, S. A., and Jakob, C. 1999. Validation and sensitivities of frontal clouds simulated by the ECMWF model. Mon. Weather Rev. 127, 2514-2531.

Kowalski, A. S., Overloop, S. and Ceulemans, R. 2000. Eddy fluxes above a Belgian, Campine forest and their relationship with predicting variables. In: Forest ecosystem modelling, upscaling and remote sensing (eds. Ceulemans, R., Veroustraete, F., Gond, V. and Van Rensbergen, J.) The Hague: SPB Academic Publishing, 3-17.

Kurbatova, J., Arneth, A., Vygodskayan N., Kolle, O., Varlagin, A., Milyukova, I., Tchebakova, N., Schulze, E.-D. and Lloyd, J. 2002. Comparative ecosystem-atmosphere exchange of energy and mass in a European Russian and a central Siberian bog I. Interseasonal and interannual variability of energy and latent heat fluxes during the snow-free period. Tellus 54B, this issue.

Legates, D. R. and Willmott, C. J. 1990. Mean seasonal and spatial variability global surface air temperature. Theor. Al. Climatol. 41, 11-21.

Lindroth, A., Grelle, A. and Morén, A.-S. 1998. Long-term measurements of boreal forest carbon balance reveal large temperature sensitivity. Glob. Change Biol. 4, 443-450.

McCaughey, J. H., Lafleur, P., Joiner, D. Jelinski, D. and Ryan, M. 1997. Magnitudes and seasonal patterns of energy, water, and carbon exchanges at a boreal young jack pine forest in the BOREAS northern study area. $J$. Geophys. Res. BOREAS Special Issue, 102, D24, $28997-$ 29008.

Malhi, Y., Baldocchi, D. D. and Jarvis, P. G. 1999. The carbon balance of tropical, temperate and boreal forests. Plant Cell Environ. 22, 715-740. 
Markkanen, T., Rannik Ü., Keronen, P., Suni, T. and Vesala, T. 2001. Eddy covariance fluxes over a boreal Scots pine forest. Boreal Environ. Res. 6, 65-78.

Milyukova, I. M., Kolle, O. E., Varlagin, A. B., Vygodskaya, N. N., Schulze, E.-D. and Lloyd, J. 2002. Carbon balance of a southern taiga spruce stand in European Russia. Tellus 54B, this issue.

Olson, J. S., Watts, J. A. and Allison, L. J. 1985. Major world ecosystem complexes ranked by carbon in live vegetation. NDP017, Carbon Dioxide Information Center, Oak Ridge National Laboratory, Oak Ridge, Tennessee, USA.

Pilegaard, K., Hummelshøj, P., Jensen, N. O. and Chen, Z. 2000. Two years of continuous $\mathrm{CO}_{2}$ eddy flux measurements over a Danish beech forest. Agric. For. Meteorol. 107, 29-41.

Parton, W. J., Scurlock, J. M. O., Ojima, D. S., Gilmanov, T. G., Scholes, R. J., Schimel, D. S., Kirchner, T., Menaut, J.-C., Seastedt, T., Moya, E. G., Kamnalrut, A. and Kinyamario, J. I. 1993. Observations and modeling of biomass and soil organic matter dynamics for the grassland biome worldwide. Global Biogeochem. Cy. 7, 785-809.

Ruimy, A., Jarvis, P. G., Baldocchi, D. D. and Saugier, B. 1995. $\mathrm{CO}_{2}$ fluxes overplant canopies and solar radiation: a review. Adv. Ecol.Res. 26, 1-68.

Ruimy, A., Dedieu, G. and Saugier, B. 1996a. TURC: a diagnostic model of continental gross primary productivity and net primary productivity. Global Biogeochem. Cy. 10, 269-285.

Ruimy, A., Kergoat, L., Field, C. B. and Saugier, B. 1996b. The use of $\mathrm{CO}_{2}$ flux measurements in models of the global terrestrial carbon budget. Glob. Change Biol. 2, $287-$ 296.

Ruimy, A., Kergoat, L., Bondeau, A. and the participants of the Potsdam NPP model intercomparison 1999.
Comparing global models of terrestrial net primary productivity (NPP): Analysis of differences in light absorption and light-use efficiency Glob. Change Biol. 5, suppl. $1,56-64$.

Schulze, E.-D., Vygodskaya, N. N., Tschebakova, N., Czimczik, C. I., Kozlov, D., Lloyd, J., Mollicone, D., Myachkova, E., Sidorov, K., Varlagin, A. and Wirth, C. 2002. The Eurosiberian transect: an introduction to the experimental region. Tellus $\mathbf{5 4 B}$, this issue.

Shibistova, O., Lloyd,. J., Kolle, O., Arneth, A., Zrazhevskaya, G., and Schulze, E.-D. 2001. Accumulation of $\mathrm{CO} 2$ in a mature forest. Proc. Russ. Acad. Sci. (in press).

Valentini, R., Matteucci, G., Dolman, A. J., Schulze, E.-D., Rebmann, C., Moors, E. J., Granier, A., Gross, P., Jensen, N. O., Pilegaard, K., Lindroth, A., Grelle, A., Bernhofer, C., Grunwald, T., Aubinet, M., Ceulemans, R., Kowalski, A. S., Vesala, T., Rannik, U., Berbigier, P., Loustau, D., Gudmundsson, J., Thorgeirsson, H., Ibrom, A., Morgenstern, K., Clement, R., Moncrieff, J., Montagnani, L., Minerbi, S. and Jarvis, P. G. 2000. Respiration as the main determinant of carbon balance in European forests. Nature 404, 861-865.

Viovy, N., Arino, O. and Belward, A. S. 1992. The Best Index Slope Extraction (BISE): a method for reducing noise in NDVI time-series. Int. J. Remote Sens., 13, 1585-1590.

Williams, M., Eugster, W., Rastetter, E. B., McFadden, J. P. and Chapin F. S. 2000. The controls on net ecosystem productivity along an Arctic transect: a model comparison with flux measurements. Glob. Change Biol. 6, 116126.

Zamolodchikov, D. G. and Karelin, D. V. 2001. An empirical model of carbon fluxes in Russian tundra. Glob. Change Biol. 6, 147-161. 